\title{
Ultralyd av bukspyttkjertelen: Oppdatering av en veletablert metode
}

Trond Engjom disputerte onsdag 13. juni 2018 for ph.d.-graden ved Universitetet i Bergen med avhandlingen: „Ultrasonography of the pancreas in Cystic Fibrosis and Chronic pancreatitis. Pancreatic ultrasound revisited“.

Ultralyd kan erstatte mer avansert billeddiagnostikk ved sykdommer i bukspyttkjertelen.

Ultralyd er en veletablert metode ved mistanke om sykdommer i bukspyttkjertelen. Metoden har betydelige fordeler når det gjelder tilgjengelighet, repeterbarhet og fravær av strålebelastning. Til tross for at det har foregått en betydelig teknologisk utvikling av metoden er litteraturen ikke oppdatert. De fleste studier som vurderer verdien av ultralyd i oppfølging av sykdommer i bukspyttkjertelen over 20 år gamle. Av denne grunn velges ofte mer kompliserte og kostbare billeddiagnostiske metoder for fremstilling av bukspyttkjertelen. Gjennom de fire arbeider som er inkludert $\mathrm{i}$ avhandlingen demonstreres hvordan moderne ultralyd teknologi kan brukes for

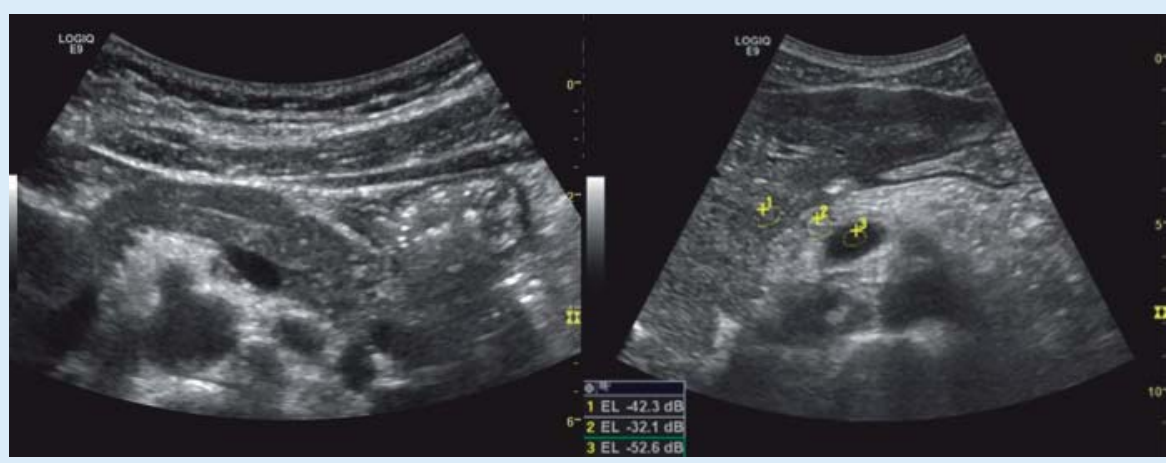

Ultralydbilder av en normal pankreas hos en pankreassuffisient CF pasient (Venstre) og av den klassiske «hvite pankreas» hos en insuffisient CF pasient (høyre).

len ved sykdommene kronisk pankreatitt og cystisk fibrose. Videre beskriver avhandlingen en nyutviklet metode for å vurdere stimulert funksjon i bukspyttkjertelen ved de samme sykdommene. Avhandlingen konkluderer med at ekstern ultralyd fremstiller forandringer i bukspyttkjertelen med god nøyaktighet. I mange tilfeller er ultralydforandringene så karakteristiske at de gir grunnlag for en umiddelbar diagnose for de aktuelle tilstander.
Ved å benytte ultralyd regelmessig i oppfølgingen av pasienter med sykdom i bukspyttkjertelen kan en oppnå tidligere diagnostikk av komplikasjoner og spare pasienter for mere strålebelastende metoder. Den nyutviklede metoden for funksjonell vurdering av bukspyttkjertel funksjon kan anvendes med god diagnostisk presisjon, spesielt ved sykdommen cystisk fibrose. 